\title{
Rancangan Sistem Informasi Aplikasi Masjid Online untuk Masyarakat di tengah Pandemic Corona
}

\author{
Ayuniar Salsabila Putri - 1201174125 \\ Telkom University \\ Email : ayuniarsp@ @elkomuniversity.ac.id
}

\begin{abstract}
Di dalam kegiatan sehari-hari dalam melakukan aktivitas, kita sering tidak menduga akan mendapatkan resiko kecelakaan pada diri kita sendiri. Banyak sekali masyarakat yang belum menyadari akan hal ini, termasuk di Indonesia baik di lingkungan kerja (perusahaan, pabrik atau kantor), tempat umum maupun di lingkungan rumah.

Indonesia masih berhadapan dengan virus COVID-19 yang mengakibatkan sebagian dari masyarakat Indonesia terjangkit penyakit virus tersebut. Jumlah kasus virus COVID-19 terus bertambah dengan beberapa melaporkan kesembuhan, tapi tak sedikit korban yang meninggal. Penularan virus corona sangat cepat hingga Organisasi Kesehatan Dunia WHO menetapkan virus corona atau COVID-19 merupakan pandemic. Akibat virus corona, banyak tenaga medis seperti dokter, perawat, petugas medis menjadi gardu terdepan untuk menghadapi pasien yang terjangkit virus tersebut. Bukan hanya itu saja, virus tersebut telah merugikan banyak negara. Untuk mencegah penyebaran virus ini semakin meluas, negara yang terjangkit virus tersebut mengambil tindakan seperti lock down, social distancing, PSBB (Pembatasan Sosial Berskala Besar). Indonesia melakukan tindakan social distancing dan PSBB untuk tindakan preventif menghadapi virus COVID-19 agar penyebaran virus tersebut tidak meluas. Sehingga dengan ada tindakan tersebut masyarakat melakukan aktivitas pekerjaan, beribadah, belajar hanya dari rumah saja.

Karena adanya wabah pandemic corona ini maka, di ciptakan Aplikasi Masjid Online karena walaupun beribadah dari rumah saja agar lebih maksimal seperti beribadah rutin di Masjid. Dalam Aplikasi tersebut sudah di sediakan kumpulan video-video ceramah, sholat wajib dan sunnah, do’a, serta piket kebersihan Masjid.
\end{abstract}

Kata Kunci : Aplikasi, COVID 19 (Wabah pandemic corona), Aplikasi Masjid Online, beribadah, 


\section{BAB I INTRODUCE \\ BUSINESS CASE}

\section{I.1. Project Definition}

Pilihan Objek Perancangan Sistem Informasi untuk mebuat suatu ide yaitu suatu organisasi pengurus rumah ibadah untuk umat muslim (Masjid). Masalah yang akan diselsaikan dengan Sistem Infomasi dengan ide ini yaitu maraknya wabah pandemic korona yang mengakibatkan seluruh masyarakat tidak boleh keluar rumah. Indonesia telah mengambil tindakan untuk pencegahan penyebaran virus korona semakin meluas yaitu tindakan PSBB (Pembatasan Sosial Berskala Besar) dan mengakibatkan banyak dampak negative bagi semua yang terkena dampaknya. Kegiatan PSBB mengakibatkan masyarakat yang khususnya beragama Islam tidak keluar rumah untuk sholat di masjid sehinggga jama'ah masjid melakukan ibadah di rumah termasuk solat Jum'at dan tidak melakukan aktivitas lain-lain yaitu bersih-bersih masjid, kerja bakti. Adanya wabah pandemic korona maka masjid jarang terurus dan terawat.

Sistem Informasi yang diusulkan berupa Sistem Aplikasi untuk mengetahui ceramah dan aktivitas-aktivitas yang selama dilakukan di masjid, piket untuk membersihkan masjid dengan teratur. Alasan membuat sistem aplikasi masjid online ini karena aktivitas yang rutin selama dilakukan sebelum wabah korona berjalan lancar seperti semula adanya aplikasi yang berbasis online yang bisa dijangkau banyak orang.

\section{I.2. Project Objective}

Akhir-akhir ini terjadinya wabah pandemic korona yang mengakibatkan seluruh masyarakat tidak boleh keluar rumah. Indonesia telah mengambil tindakan untuk pencegahan penyebaran virus korona semakin meluas yaitu tindakan PSBB (Pembatasan Sosial Berskala Besar) dan mengakibatkan banyak dampak negative bagi semua yang terkena dampaknya. Kegiatan PSBB mengakibatkan masyarakat yang khususnya beragama Islam tidak keluar rumah untuk sholat di masjid, beli makanan dan minuman untuk berbuka puasa dan melakukan hal rutin sebelum adanya wabah pandemic korona. Sehingga, masjid-masjid sekitar rumah atau dimanapun jarang terurus dengan baik dan hanya diurusi oleh marbot masjid. Maka dari aplikasi masjid online ini maka diharapkan pencapaian sistem aplikasi masjid online yaitu : 
- Masyarakat bisa mengetahui jadwal piket kebersihan di masjid dan bisa saling gotong royong untuk membersihkan masjid

- Masyarakat mengetahui ceramah dan khutbah dari ustadz yang pernah mengisi di masjid sekitar rumah dari video ceramah dan khutbah yang tersedia di aplikasi masjid online

- Masyarakat mengetahui cara gerakan sholat yang baik, do'a-do'a setelah sholat, mengenal sholat wajib dan sunnah dari video tutorial shalat dan do'a yang tersedia di aplikasi masjid online.

\section{I.3. System Definition}

Sistem Informasi untuk pembuatan ide ini yaitu Sistem Aplikasi/Web. Indikator Performansi yang akan meningkat jika usulan ide sudah diterapkan yaitu :

- Adanya kumpulan video ceramah / khutbah dari para Ustadz-Ustadz dari masjid tersebut.

- Adanya jadwal piket yang dilakukan oleh masyarakat dan marbout untuk kerja bakti, saling gotong royong maupun pembersihan masjid secara rutin

- Adanya kumpuoan video tuntunan do'a, dan solat .

Tujuan dari Sistem Informasi dalam usulan Aplikasi / Web ini yaitu:

- Mengetahui ceramah dan aktivitas-aktivitas yang selama dilakukan di masjid

- Mengetahui jadwal piket agar masjid terawat

- Meningkatkan mutu ibadah umat muslim karena adanya video tutorial do'a dan sholat serta ceramah \& khutbah dari para Ustadz. 


\section{BAB II \\ SYSTEM REQUIREMENTS}

\section{II.1. System Function}

Fungsi utama diterapkannya Sistem Informasi berupa Sistem Aplikasi / Web dalam suatu organisasi adalah sebagai berikut :

1. Meningkatkan efisiensi dan efektifitas data yang tersaji akurat dan tepat waktu

2. Meningkatkan produktifitas dan penghematan biaya dalam suatu organisasi

3. Meningkatkan kualitas sumber daya manusia karena unit sistem kerja yang terkoordinir dan sistematis.

\section{II.2. System Feature}

Aplikasi Masjid Online adalah salah satu sistem software untuk memudahkan umat Muslim yang terkena dampak wabah pandemic korona. Apikasi ini mencakup:

- Data-data jadwal piket kebersihan

- Data video-video tutorial Sholat dan Do'a.

- Data-data video ceramah dan khutbah dari para Ustadz

Seluruh fitur tersebut saling berkaitan tersedia dalam satu aplikasi dan praktis untuk para user yang ingin memaksimalkan ibadahnya. Dengan menerapkan fitur-fitur ini, para user mudah menggunakan aplikasi masjid online.

\section{II.3. Acceptance Criteria}

Berikut merupakan acceptance sampling (kriteria penerimaan) yang ditulis untuk fiturfitur umum yang ada di sebagian besar situs web dan aplikasi yaitu user. Dalam acceptance sampling kita menggunakan cerita user yang sedang menjelaskan fitur pencarian halaman aplikasi atau web. Contoh :

Sebagai pengguna aplikasi/web

Saya ingin bisa mencari sesuatu di webpage

Jadi, saya bisa menemukan informasi yang diperlukan 
Menurut template Given/ When/ Then, kriteria penerimaan adalah sebagai berikut : User mencari item dengan namanya, "Mengingat bahwa saya berperan sebagai pengguna terdaftar atau tamu, Ketika saya membuka halaman "Produk", Kemudian sistem menunjukkan kepada saya daftar semua produk dan sistem menunjukkan bagian "Cari" di sudut kanan atas layar Ketika saya mengisi kolom "Cari" dengan nama item yang ada di daftar produk dan saya mengklik tombol "Terapkan" atau tekan tombol Enter pada papan ketik. Kemudian sistem menampilkan produk di bagian Hasil Pencarian dengan nama produk yang cocok dengan nama produk yang dimasukkan Dan sistem menunjukkan jumlah hasil pencarian di bagian atas bagian Hasil Pencarian ”

Berikut merupakan acceptance sampling (kriteria penerimaan) yang menampilkan acceptance sampling (kriteria penerimaan) Halaman Formulir Feedback bagi user. Contoh :

Sebagai pengguna aplikasi/web

Saya ingin bisa mengumpulkan feedback

Sehingga, pemilik situs web dan aplikasi dapat mempertimbangkan pendapat atau kekhawatiran saya selama pembaruan situs web / aplikasi di masa mendatang.

\section{Kriteria penerimaan untuk fungsionalitas ini adalah:}

Pengguna mengirimkan formulir umpan balik dengan data yang valid

"Mengingat saya berperan sebagai pengguna login atau tamu, Saat saya membuka halaman Umpan Balik, Kemudian sistem menunjukkan kepada saya formulir Kirim Umpan Balik yang berisi bidang "Email", "Nama" dan "Komentar" yang diperlukan.

Ketika saya mengisi bidang "Email" dengan alamat email yang valid

Dan saya mengisi bidang "Nama" dengan nama saya

Dan saya mengisi kolom "Komentar" dengan komentar saya

Dan saya klik tombol "Kirim Umpan Balik"

Kemudian sistem mengirimkan tanggapan saya

Dan sistem menunjukkan pesan kilat "Anda telah berhasil mengirimkan umpan balik Anda"

Dan sistem membersihkan bidang formulir Kirim feedback" 


\section{II.5. System User Level}

Dalam aplikasi atau web menyediakan fitur-fitur yang lengkap. Salah satu fitur yang penting dalam suatu web atau aplikasi adalah user level atau hak akses biasa juga disebut dengan role. Fitur ini sangat penting ketika web atau aplikasi di kelola oleh banyak user. Dengan fitur ini anda dapat membatasi hak akses pada user tertentu seperti jika user tersebut hanya berperan sebagai penulis, maka tidak perlu di beri akses admin yang dapat mengubah pengaturan teknikal $w e b$ atau aplikasi . hal ini dimaksudkan agar peran user dapat lebih terstruktur dan rapih, juga menghindari human error. Untuk pembagiannya sendiri User Role yang ada di web atau aplikasi di bagi menjadi 5 jenis yaitu :

\section{Administrator}

User dengan jenis role administrator merupakan user dengan kedudukan tertinggi dan memiliki semua hak akses. User ini dapat dengan bebas melakukan perubahan apapun pada website yang dikelolanya. Administrator mendapat hak akses kesemua fitur yang ada di aplikasi seperti manajemen user, pergantian tampilan website atau tamplate, log in, manajemen kategori, pengaturan media dan file, moderasi komentar dan juga pengaturan dasar wordpress seprti tanggal, jenis tulisan dan lainnya.

\section{Editor}

Lalu dibawah setingkat dengan admin yaitu Editor. Editor memiliki hak akses yang sama seperti Administrator seperti post, manajemen page, kategori dan lainnya. yang membedakan editor dan adminstrator adalah editor tidak dapat mengatur hak akses pada user lain, log in dan juga tema.

\section{Author}

Selanjutnya ada Author, untuk author memiliki hak akses untuk post artikel dan mengedit artikel yang di post nya sendiri, serta berhak melakukan upload file. perbedaannya dengan editor, author tidak dapat melakukan moderasi komentar, meskipun komentar tersebut ada di artikel yang dia tulis sendiri.

\section{Contributor}

Contributor berada di bawah author, user level jenis ini hanya dapat menulis artikel dan mengeditnya. untuk pengeditan, contributor hanya dapat mengedit artikell yang di tulisnya sendiri. berbeda dengan author, saat mempublikasikan artikel, user level jenis ini harus mendapat persetujuan dulu dari user Level Administrator atau Level Editor, dengan kata 
lain contributor tidak bisa mempublish tulisannya sendiri. Artikel yang telah di publish oleh Administrator atau Editor tidak dapat diedit/dihapus lagi oleh contributor.

\section{Subscriber}

Terakhir ada user level subscriber, user level ini adalah level yang terendah. Subscriber dapat membaca, dan memberikan komentar. Kelebihan subscriber dibandingkan dengan pengunjung biasa (guest user) adalah, subscriber dapat membaca post yang di "private" dan mengomentari post yang kolom komentarnya telah dilimit/dibatasi atau dibuat ketentuan "Users must be registered and logged in to comment" pada menu Discussion Settings.

\section{II.6. Penjelasan Singkat Terkait Metode}

Metode yang digunakan adalah metode observasi dan mentode waterfall. Observasi atau pengamatan langsung terhadap masalah yang dihadapi pengurus Masjid Al-Fath Cikampek Karawang serta masyarakat beragama muslim observasi dilakukan dengan observasi berstruktur dengan menyiapkan daftar kebutuhan data dan sumber data. Metode Waterfall digunakan karena dimana team akan melakukan proses pengumpulan requirement, analisa, design, dan programming, Testing, dll yang dilakukan secara tahap demi tahap. Waterfall bertujuan untuk menghasilkan suatu Software/sistem pada suatu waktu yang telah ditentukan dengan kualitas terbaik. Waterfall mengutamakan interaksi dengan Stakeholders di awal-awal project dikerjakan untuk mendapat gambaran yang jelas. Dan saat menggunakan proses Waterfall setiap team aplikasi menyelesaikan suatu tahap, maka team harus lanjut ke tahap berikutnya dan diharapkan tanpa mengulang proses sebelumnya. 


\section{BAB III}

\section{SYSTEM DESIGN}

\section{III.1. Business Requirement}

1. Stakeholder
a. Owner
: CEO
b. User
: Masyarakat yang beragama islam dan CEO, admin
c. Customer
: Masyarakat yang beragama islam di Masjid Al-Fath
d. Analyst
: Pengurus Masjid Al-Fath

2. User Role
a. Customer
: Memilih menu utama antara video solat dan do'a, ceramah
b. Sales
: Input data ke aplikasi. Melihat permintaan dari customer, laporan seluruh kunjugan ke aplikasi Masjid Al-Fath Online
c. CEO/admin : Memantau aktivitas yang ada di aplikasi

3. Proses Bisnis Eksisting

Pengurus Masjid Al-Fath menawarkan sebuah video tutorial sholat, do'a, ceramah secara online melalui aplikasi selama adanya wabah pandemic corona.

4. Proses Bisnis Usulan

Berfokus hanya jasa yang akan ditawarkan oleh Pengurus Masjid Al-Fath seperti video tutorial sholat, do'a, ceramah. User dapat memilih jasa yang diinginkan dari video tutorial sholat, do'a, ceramah sehingga admin (Pengurus Masjid Al-Fath) menambahkan video tutorial sholat, do'a, ceramah agar memperoleh rating yang bagus. 


\section{III.2. DFD (Data Flow Diagram)}

Berikut merupakan DFD Level 0 dari Sistem Aplikasi Masjid Online yaitu:

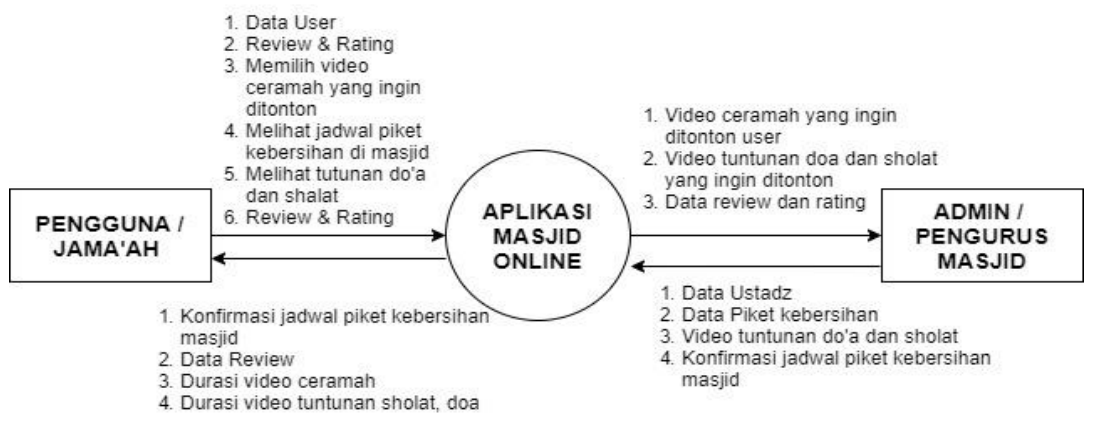

Gambar III.2. 1 DFD Level 0

Berikut merupakan DFD Level 1 dari Sistem Aplikasi Masjid Online yaitu:

DFD Level 1

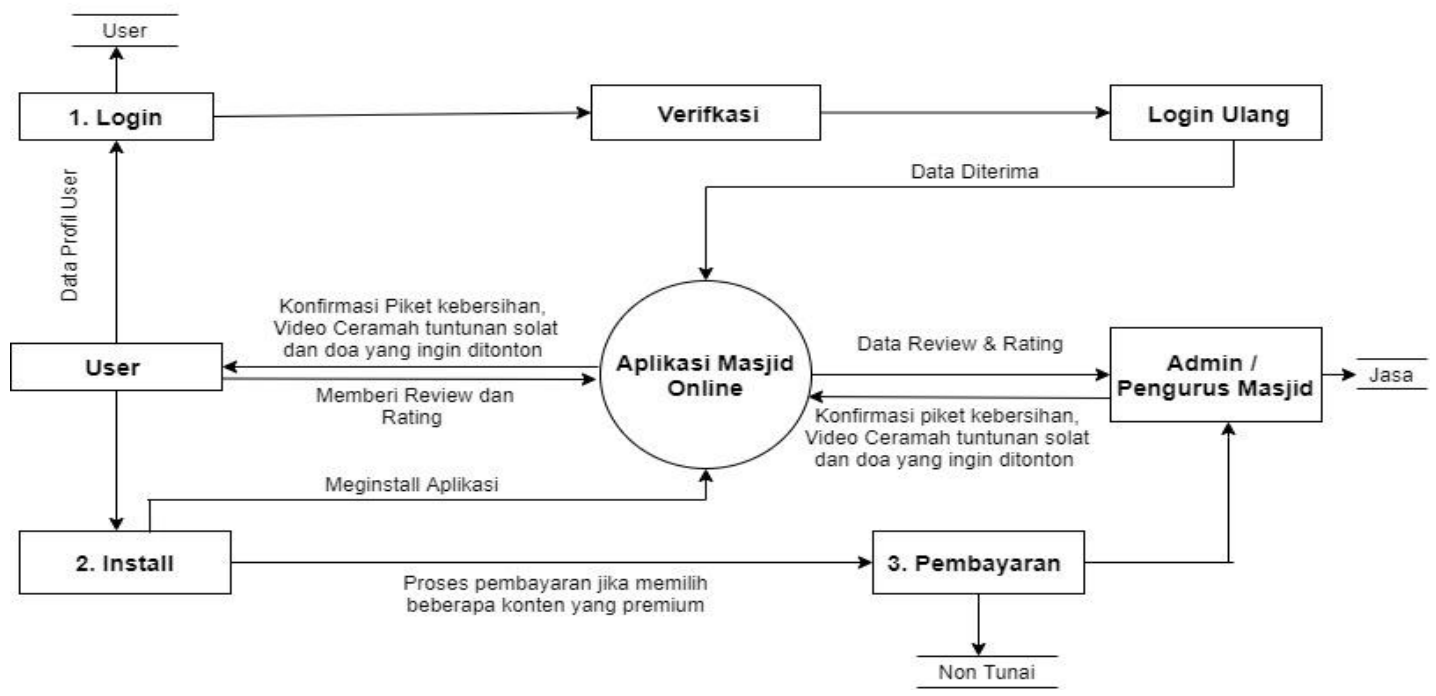

Gambar III.2. 2 DFD Level 1 
Berikut merupakan DFD Level 2 dari Sistem Aplikasi Masjid Online yaitu:

DFD Level 2 Proses 1 Login

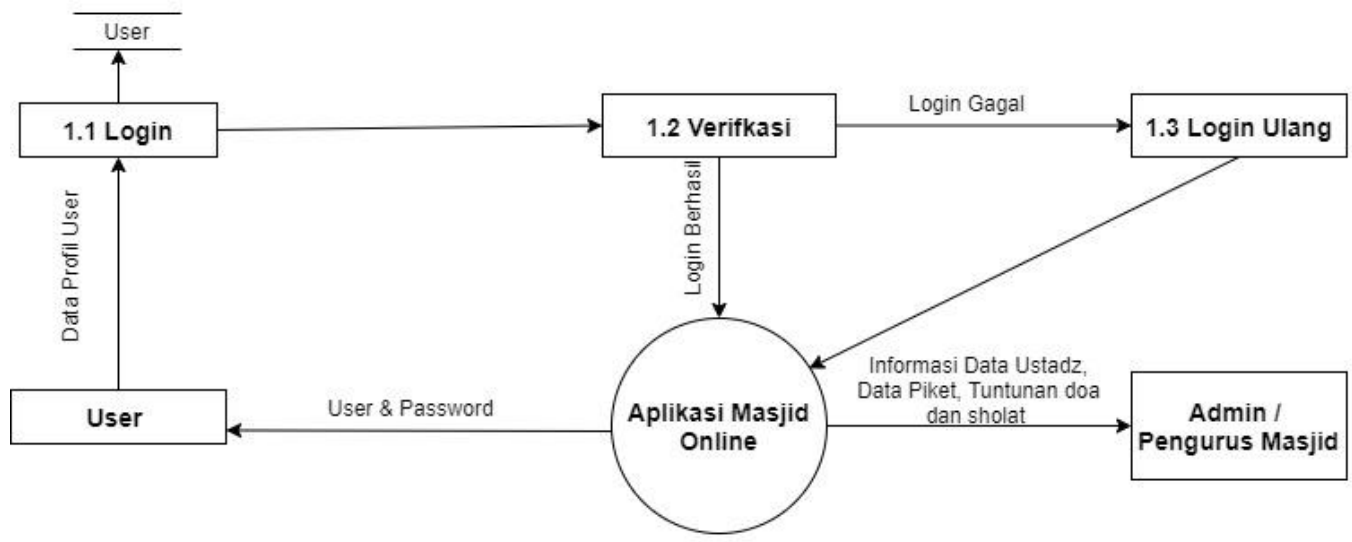

DFD Level 2 Proses 2 Menginstall

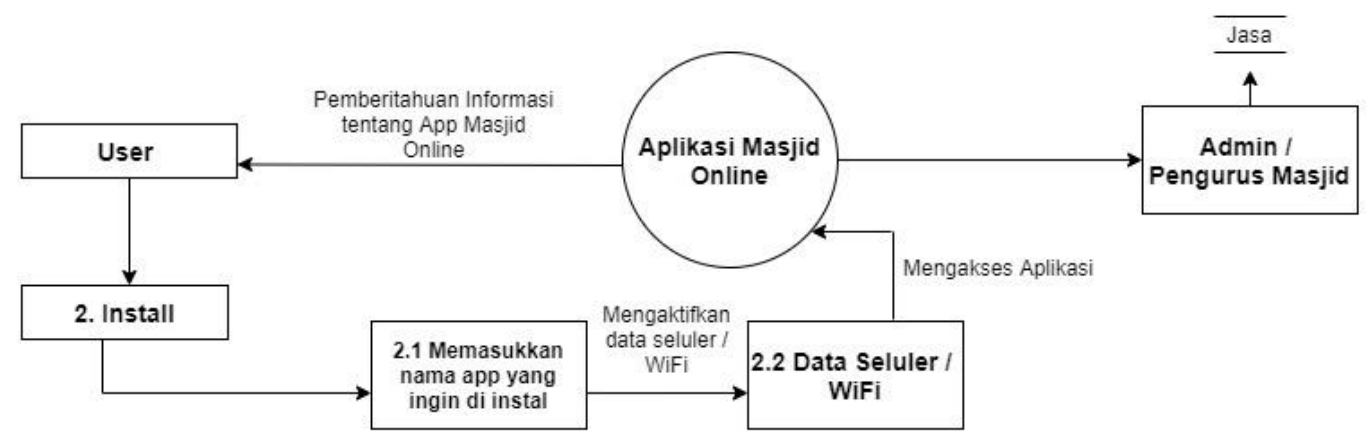

DFD Level 2 Proses 3 Pembayaran

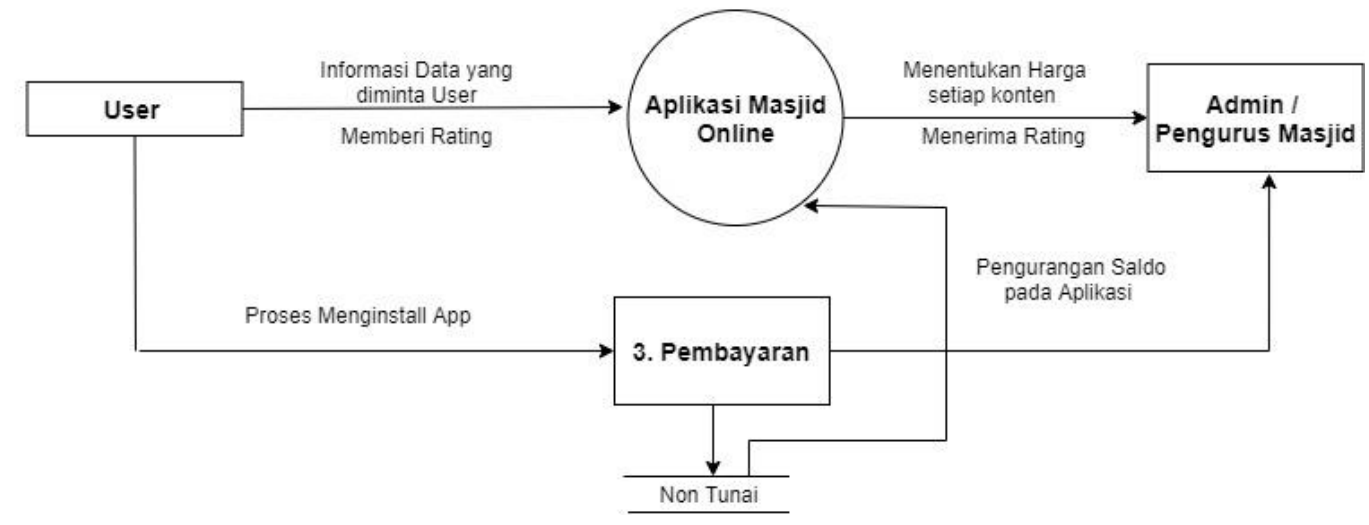

Gambar III.2. 3 DFD Level 2 


\section{III.3. ERD (Entity Relationship Diagram)}

Berikut merupakan ERD (Entity Relationship Diagram) dari Sistem Aplikasi Masjid Online yaitu:

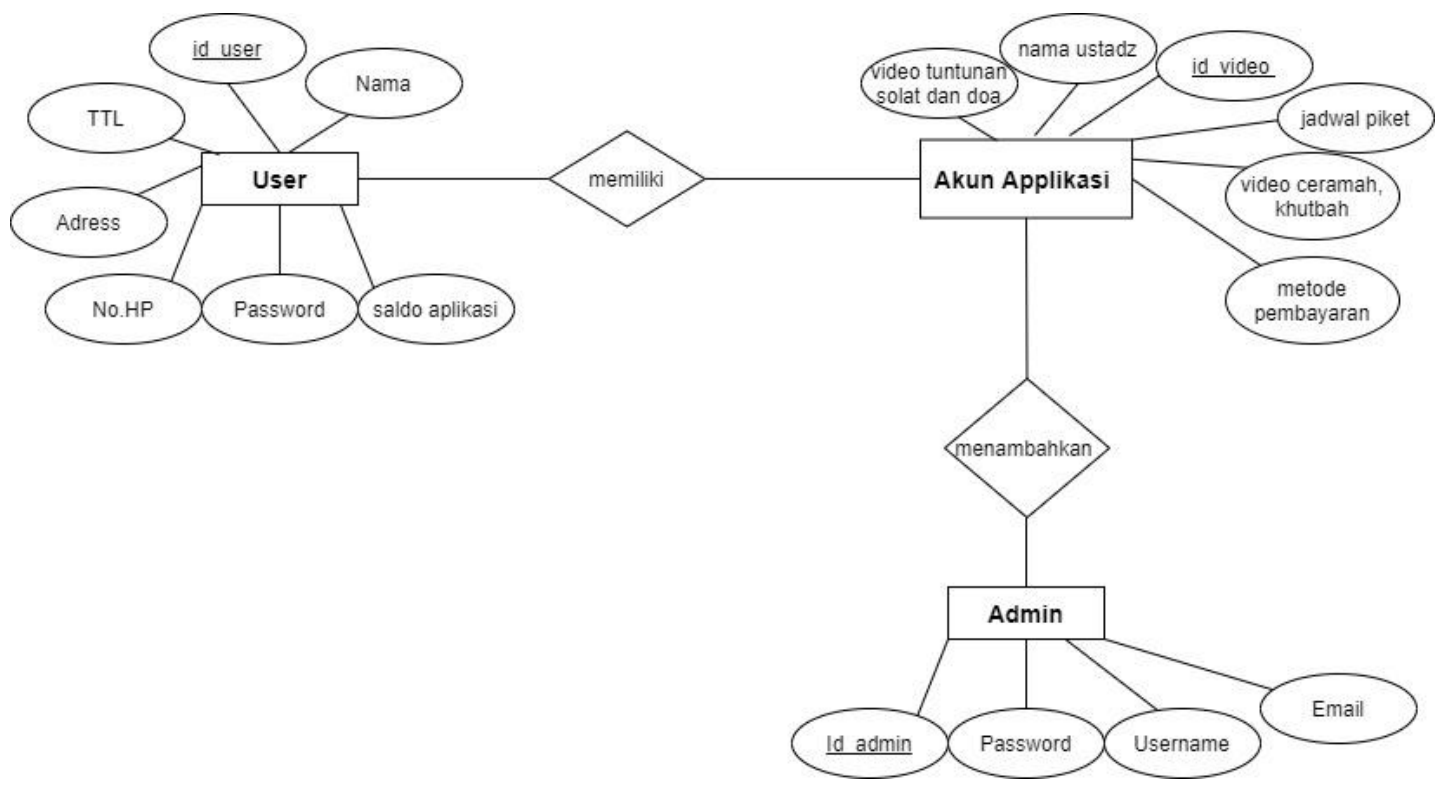

Gambar III.3. 1 ERD dari Sistem Aplikasi Masjid Online

\section{III.4. Database Design}

\begin{tabular}{|c|c|c|c|c|c|c|c|}
\hline SENIN & SELASA & RABU & KAMIS & JUMAT & SABTU & MINGGU & Keterangan \\
\hline Pak Jumadi & Pak Ari & Pak Bambang & Pak Narwin & Pak Sukimin & Pak Sukismo & Pak Subiyanto & \\
\hline Pak Narwin & Pak Sishadi & Pak Yoyok & Pak Susilo & Pak Hariyanto & Pak Sriyanto & Pak Junaidi & \\
\hline Pak Gumiwang & Pak Dimas & Pak Luthfi & Pak Alif & Pak Kurnia & Pak Agus & Pa Setyo & \\
\hline Pak Aziz & Pak Feriel & Pak Radit & Pak Iqbal & Pak Irfan & Pak Andi & Pak Rendi & \\
\hline Pak Otong & Pak Tukimin & Pak Indra & Pak Gunawan & Pak Wahid & Pak Joko & Pak Hilmi & \\
\hline
\end{tabular}

Friday, May 15, 2020

Gambar III.4. 1 Database Design Data Piket Kebersihan Masjid Al-Fath 


\begin{tabular}{|ccccc}
\hline & & USER & & \\
& & & \\
ID & ID USER & NAMA & STATUS & PASSWORD \\
\hline 4 & USER04 & SALSABILA & ADMIN & $* * *$ \\
\hline 1 & USER01 & ANWAR & ADMIN & $* * *$ \\
\hline 2 & USER02 & SISHADI & USER & $* * *$ \\
\hline 3 & USER03 & AYUNIAR & USER & $* * * * *$ \\
\hline
\end{tabular}

Gambar III.4. 2 Database Design User Masjid Al-Fath

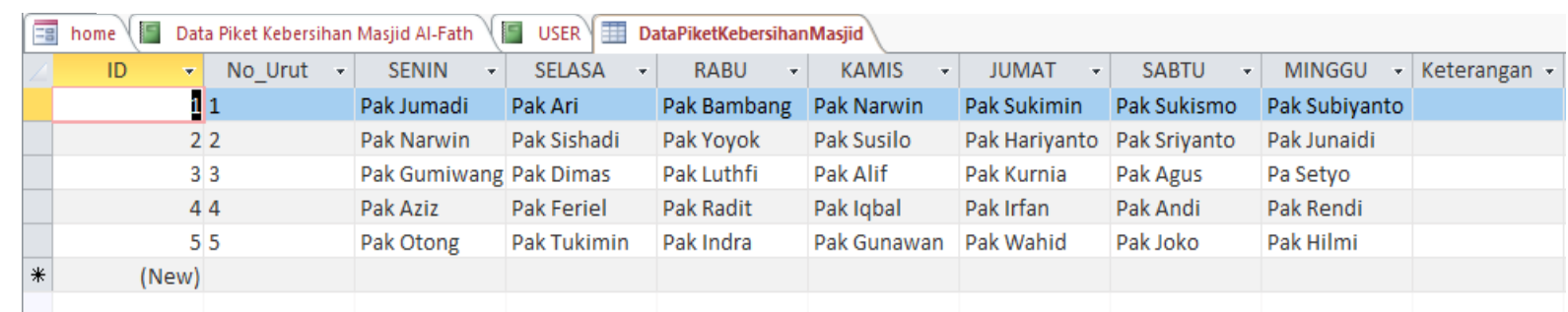

Gambar III.4. 3 Database Tables Piket Kebersihan Aplikasi Masjid Al-Fath Online

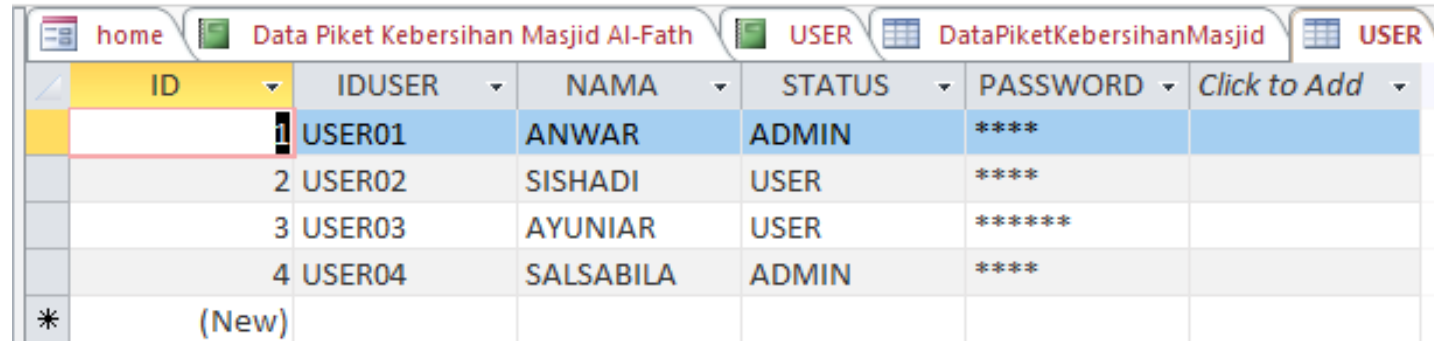

Gambar III.4. 4 Database Tables User Masjid Al-Fath Online

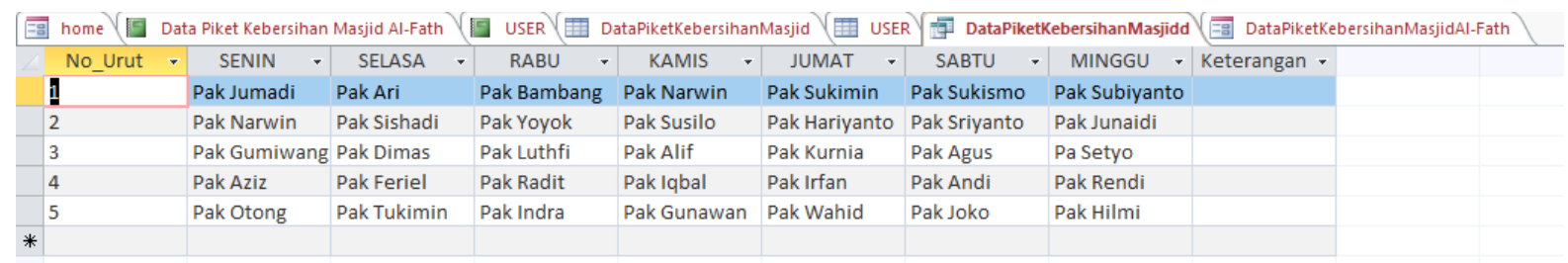

Gambar III.4. 5 Database Queries Piket Kebersihan Masjid Al-Fath 


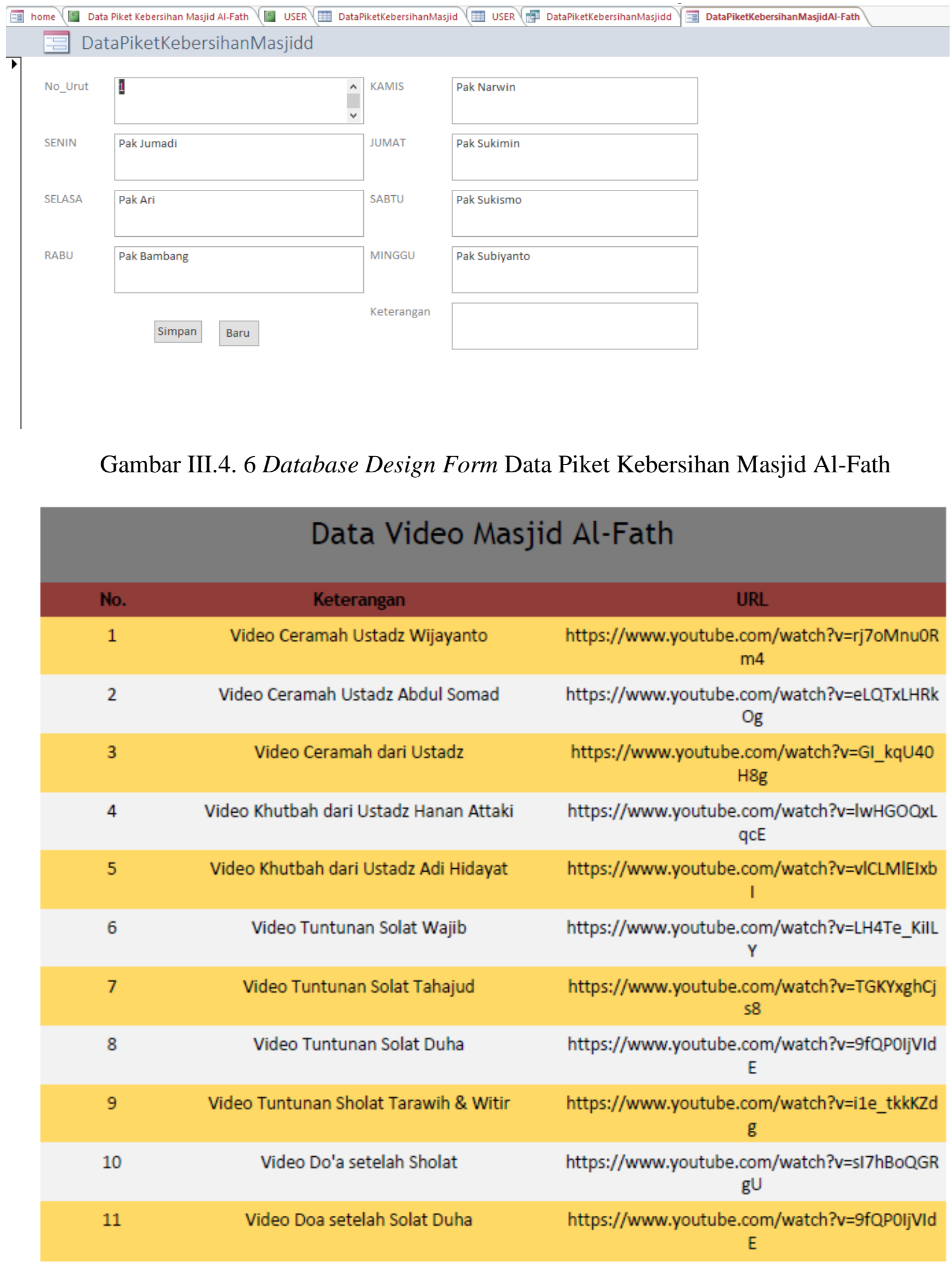

Gambar III.4. 7 Database Design Data Video Masjid Al-Fath 


\section{III.6. Use Case Diagram}

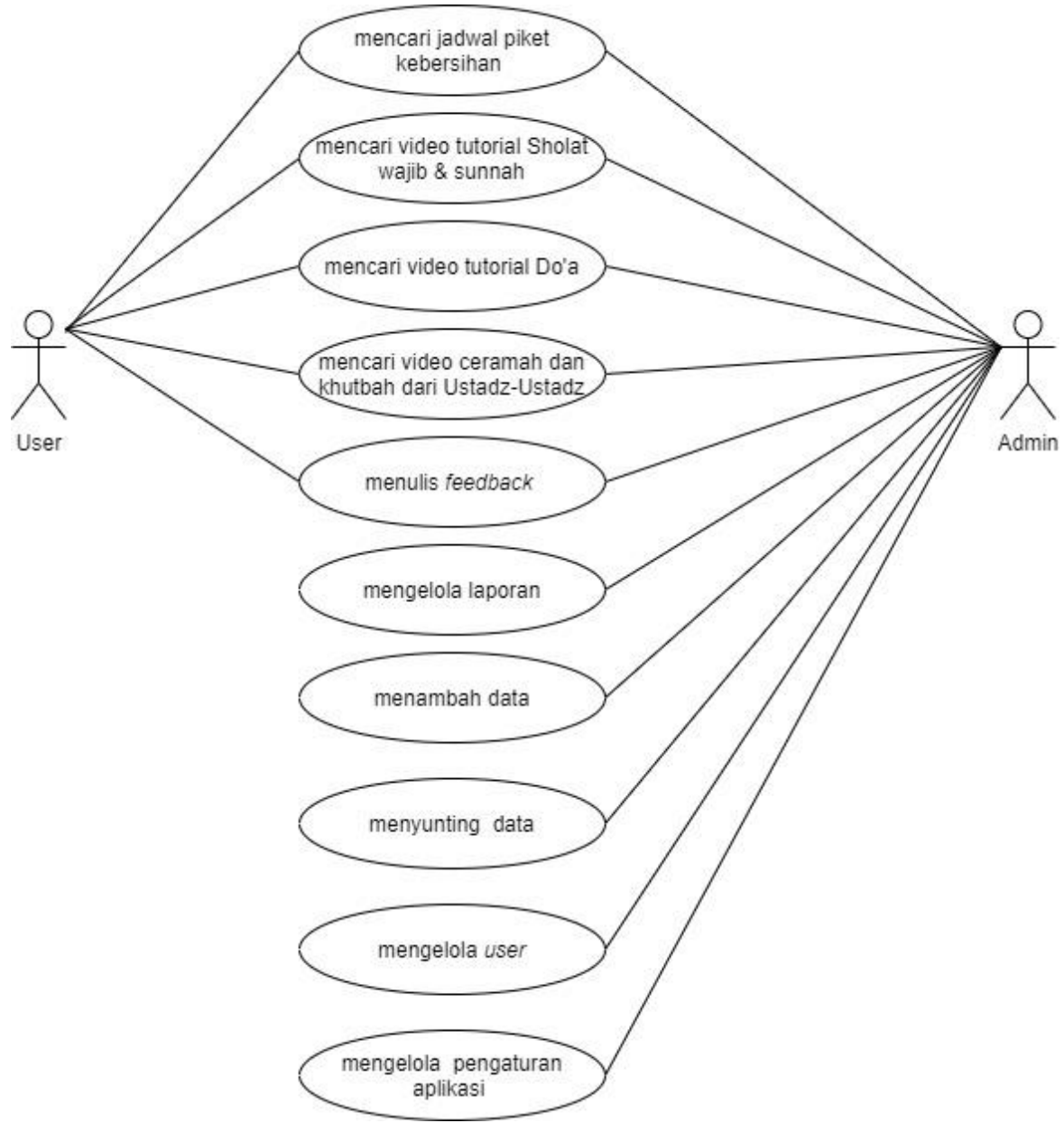

Gambar III.6. 1 Use Case Diagram Aplikasi Masjid Al-Fath Online 


\section{III.7. Activity Diagram}

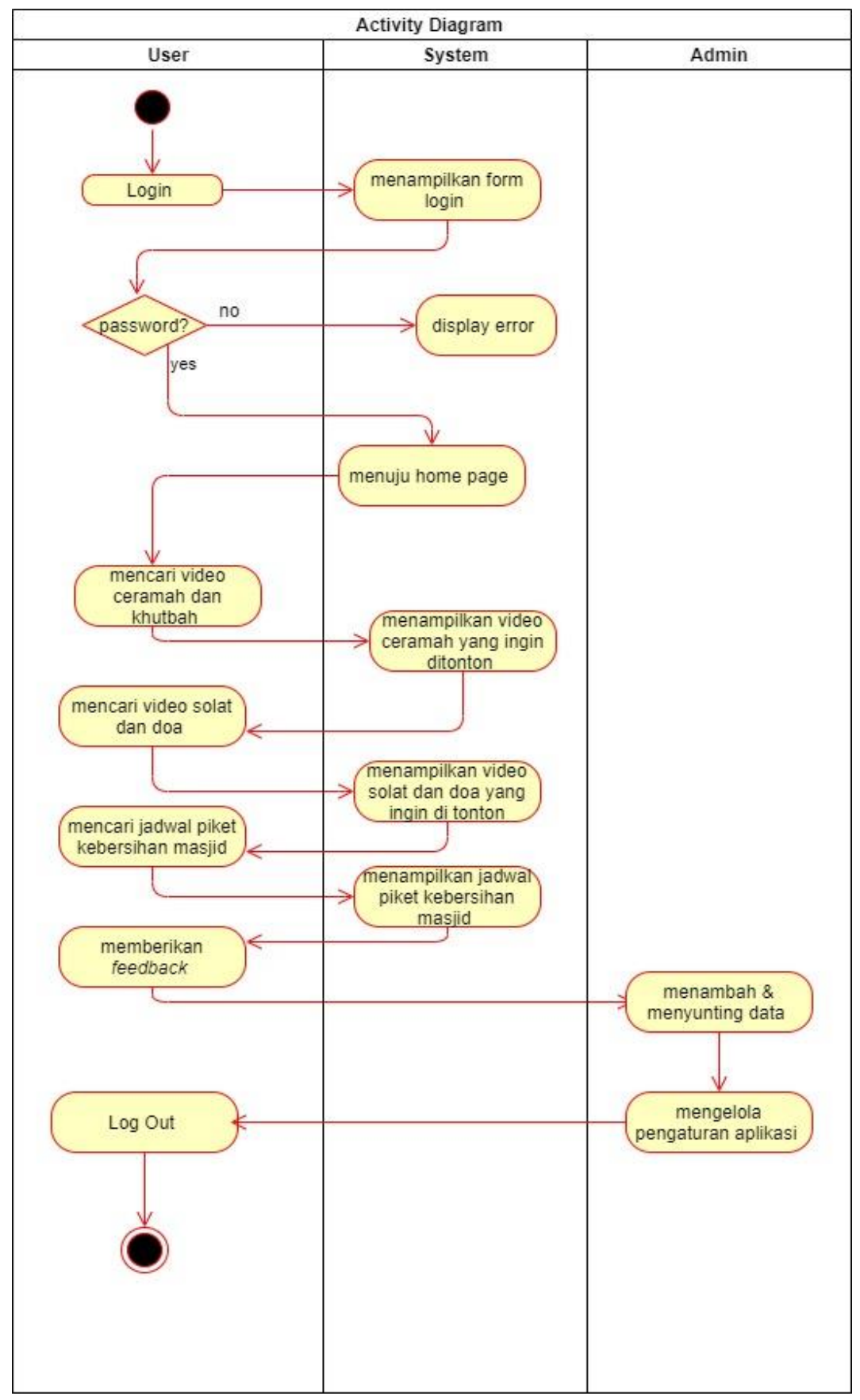

Gambar III.7. 1 Activity Diagram Aplikasi Masjid Al-Fath Online 


\section{III.8. Sequence Diagram}

Berikut merupakan Sequence Diagram dari Sistem Aplikasi Masjid Online yaitu :

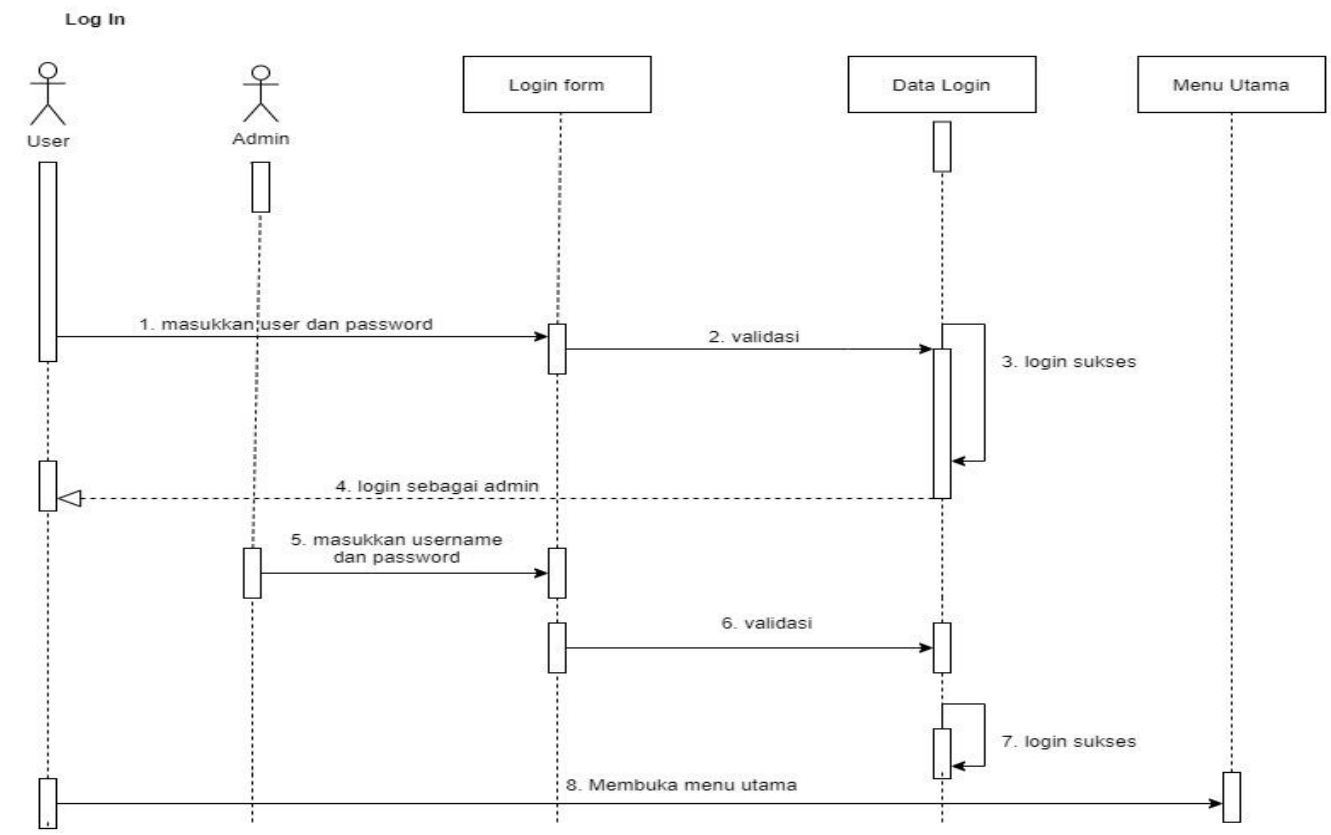

Memilih menu dalam Aplikasi
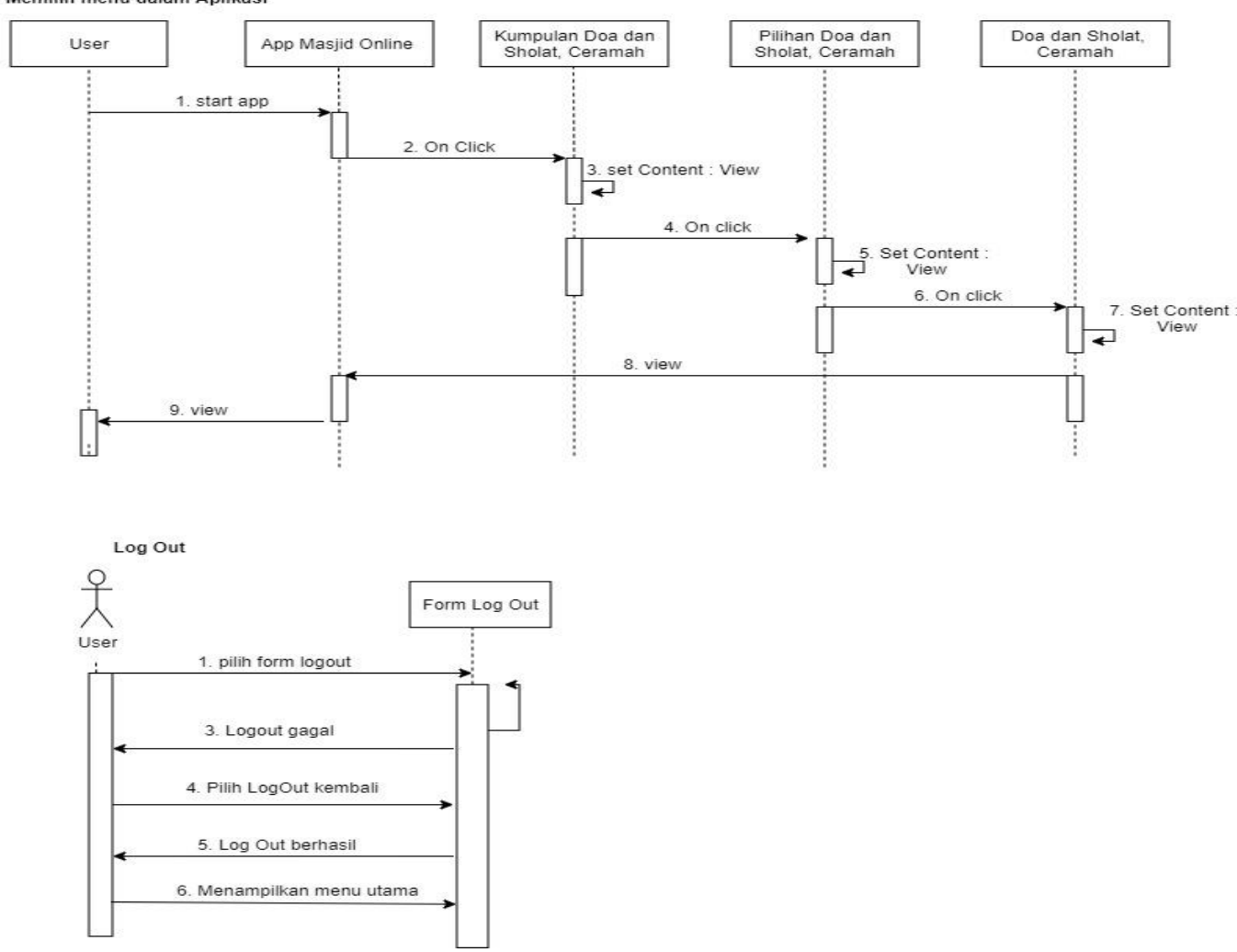

Gambar III.8. 1 Sequence Diagram Aplikasi Masjid Al-Fath Online 


\section{BAB IV}

\section{INTERFACE DESIGN}

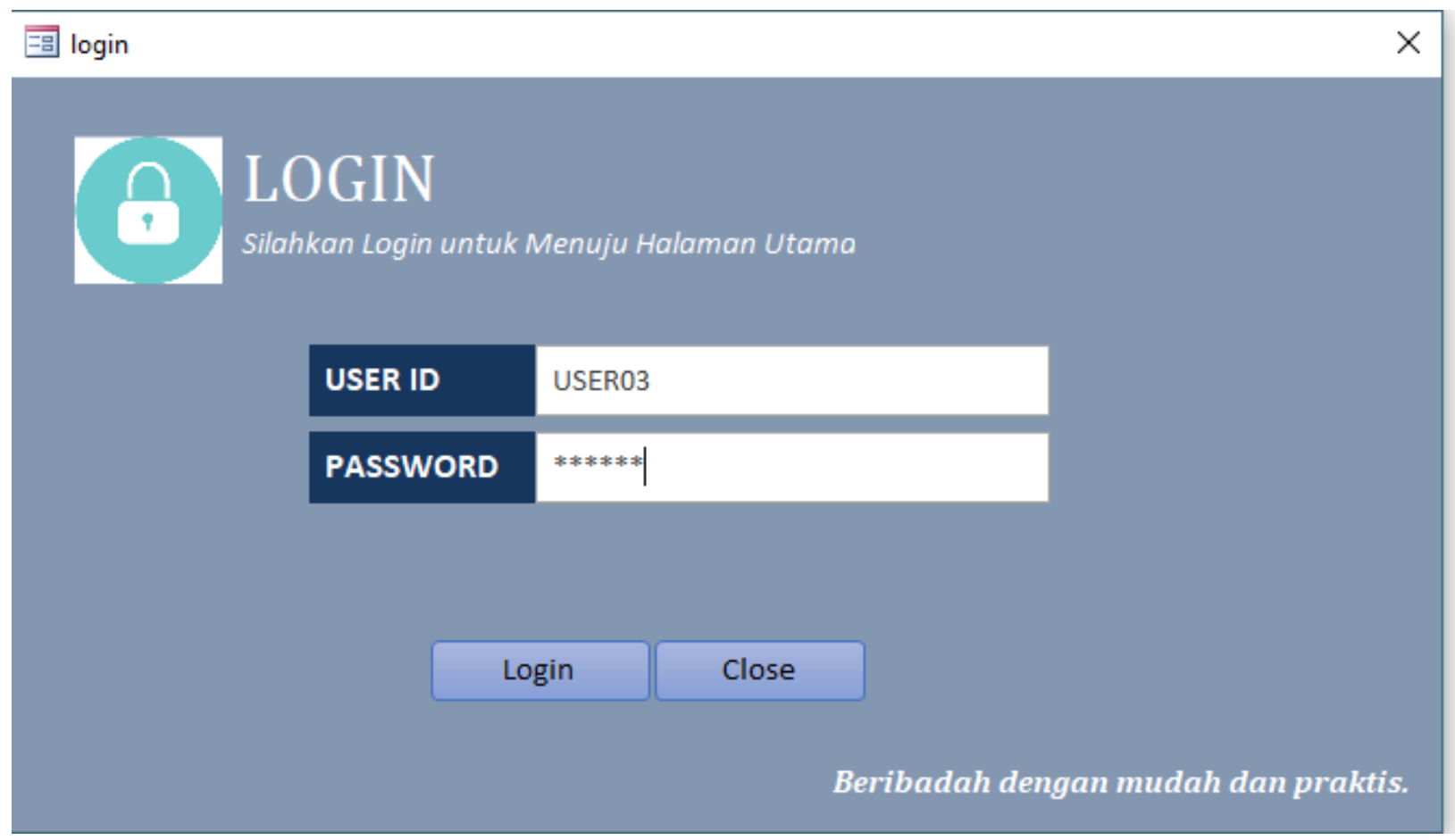

Gambar IV. 1 Interface Design Forms Login Page di Aplikasi Masjid Al-Fath Online

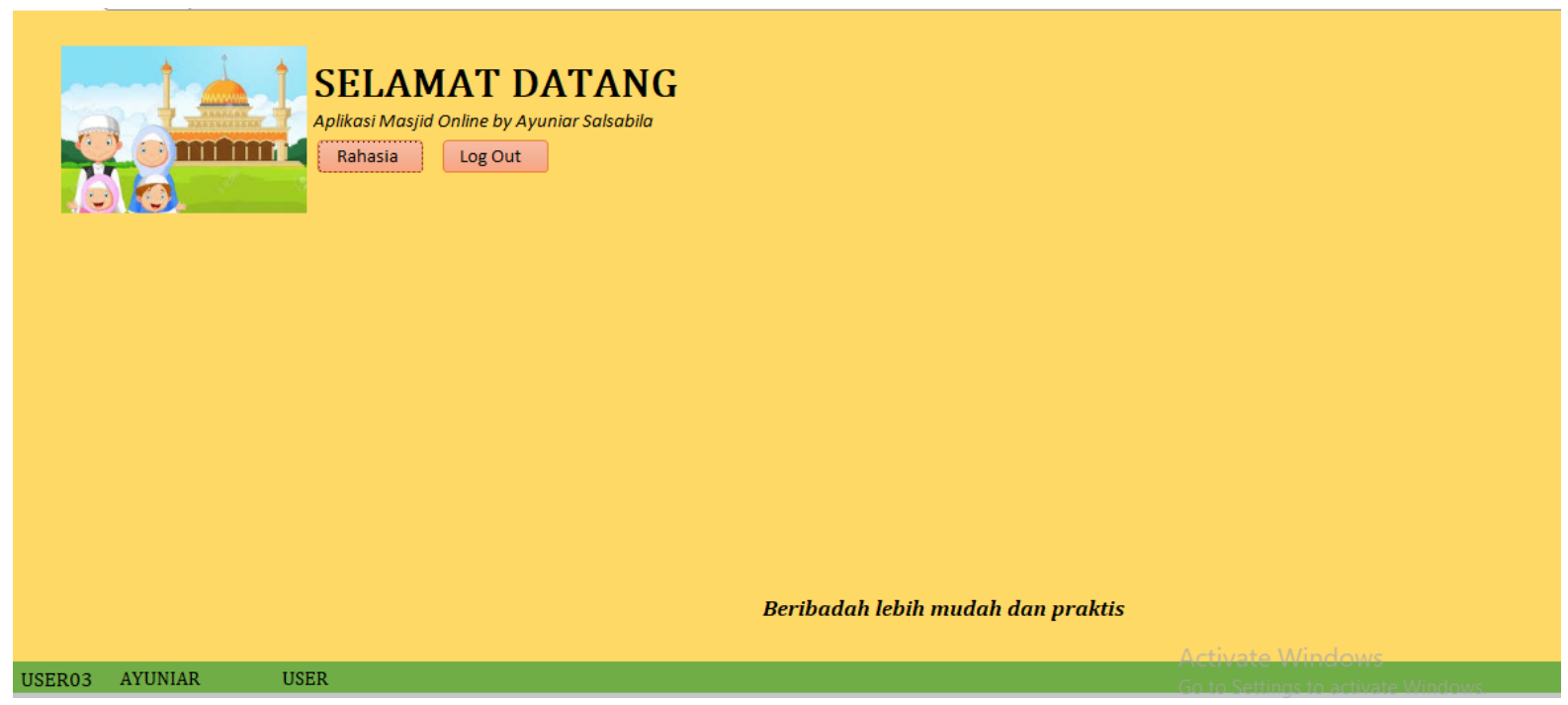

Gambar IV. 2 Interface Design Forms Home Page di Aplikasi Masjid Al-Fath Online 


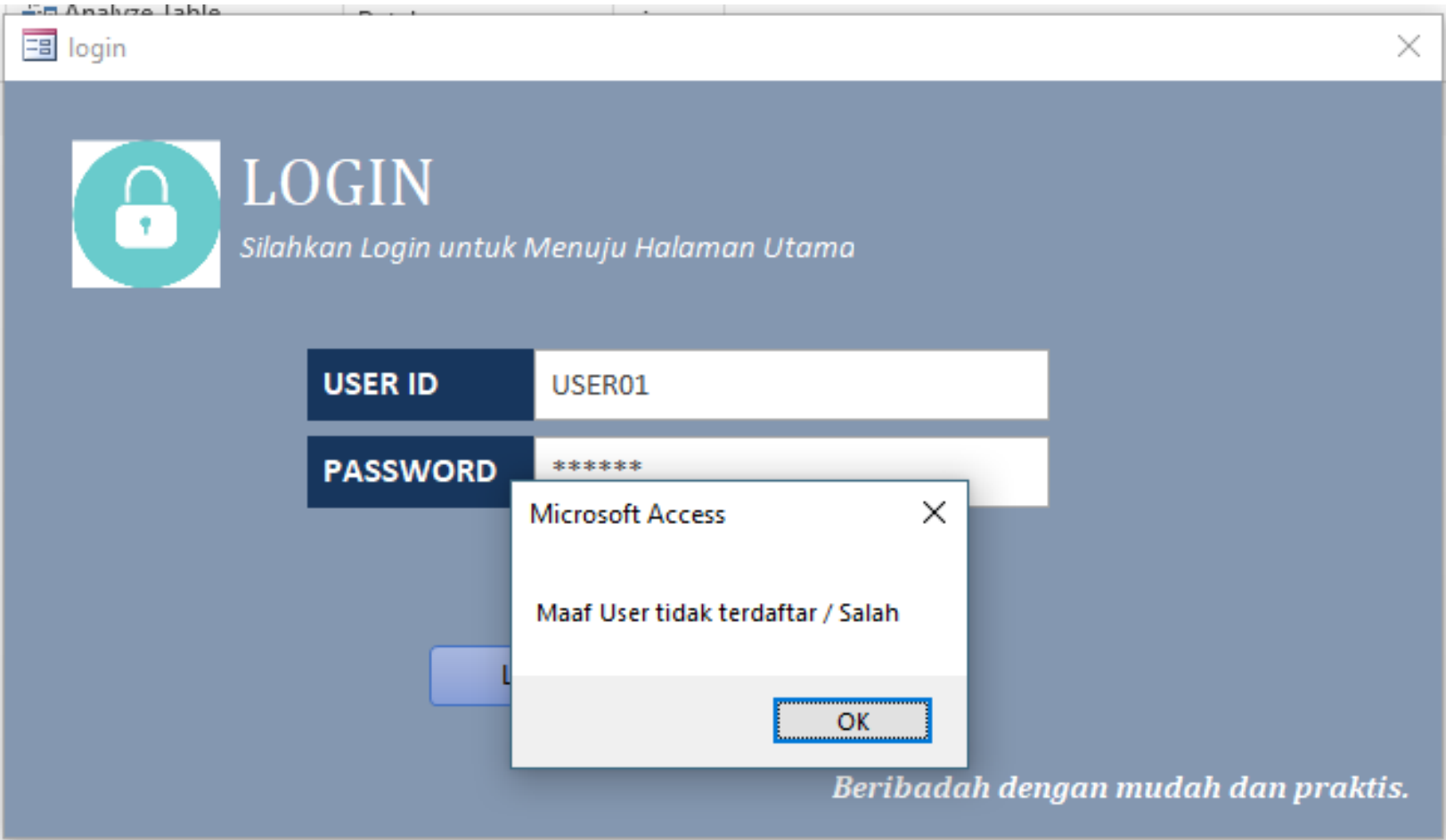

Gambar IV. 3 Interface Design Forms Login Page di Aplikasi Masjid Al-Fath Online jika username dan password salah

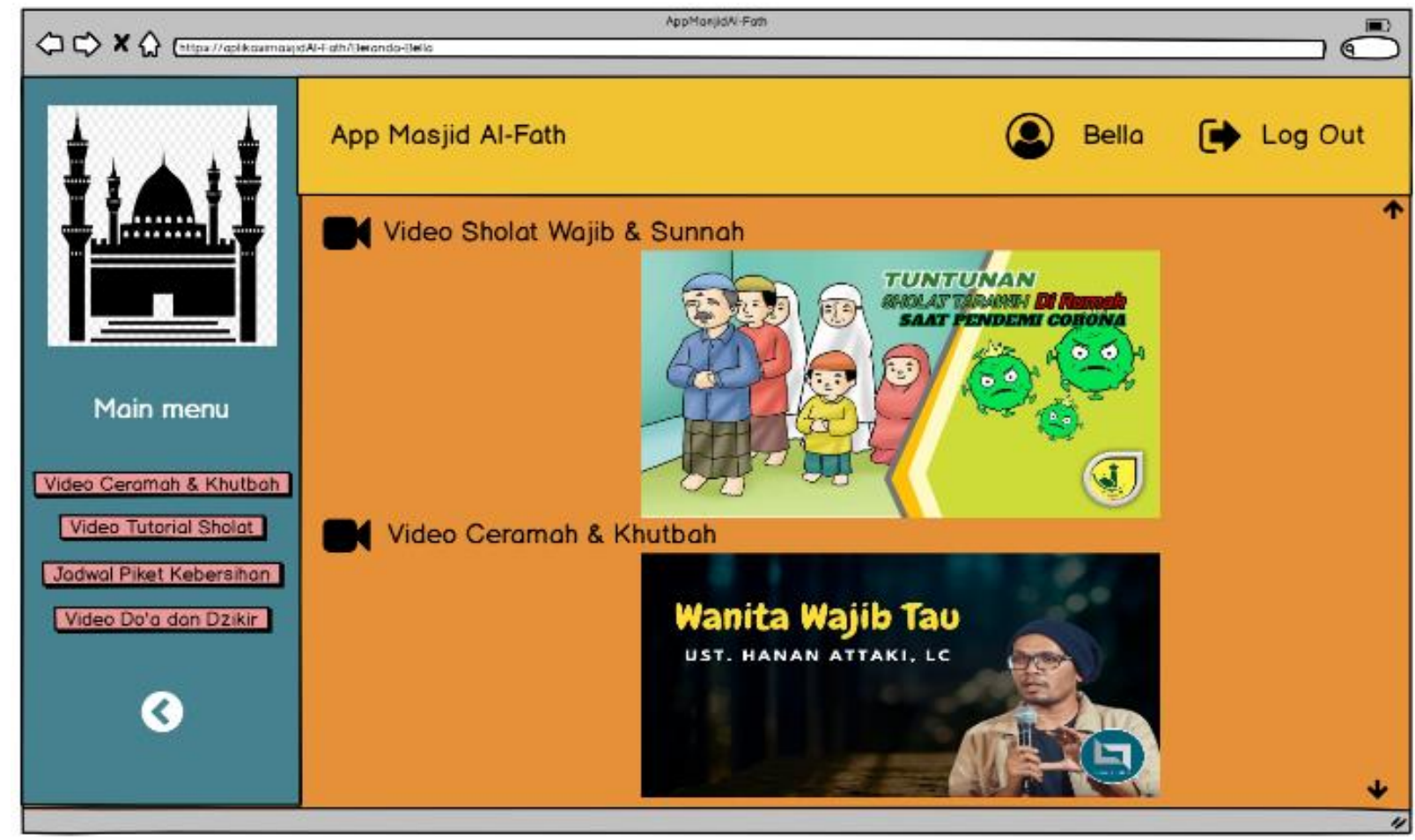

Gambar IV. 4 Interface Design Beranda di Aplikasi Masjid Al-Fath Online 


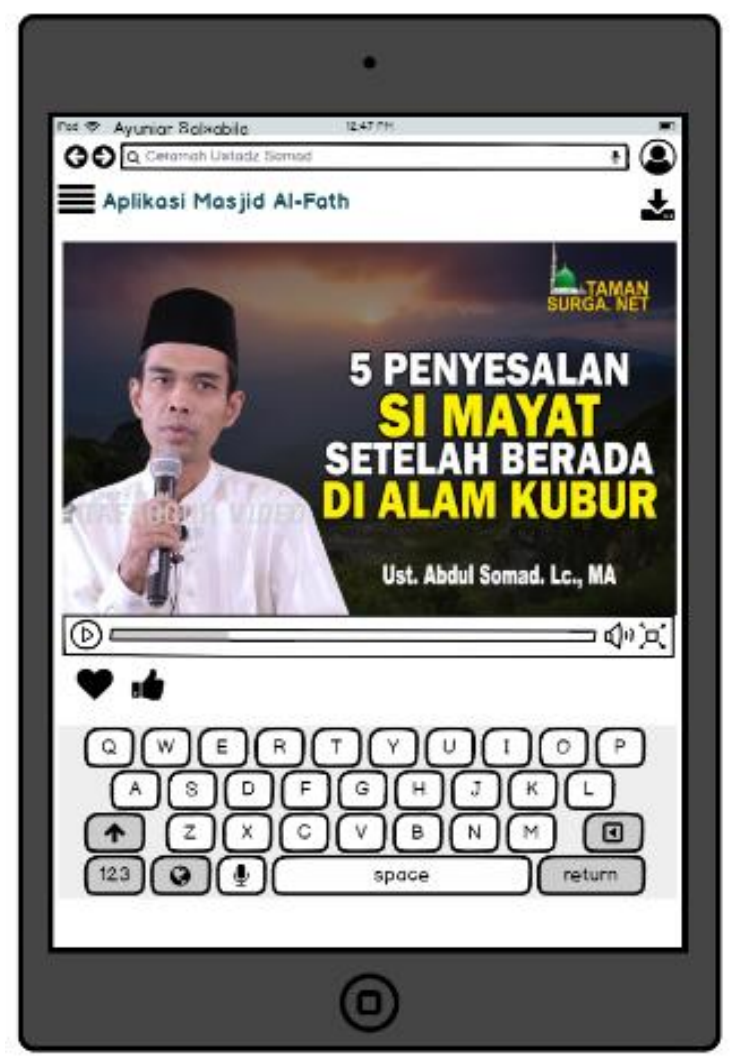

Gambar IV. 5 Interface Design Video Ceramah di Aplikasi Masjid Al-Fath Online

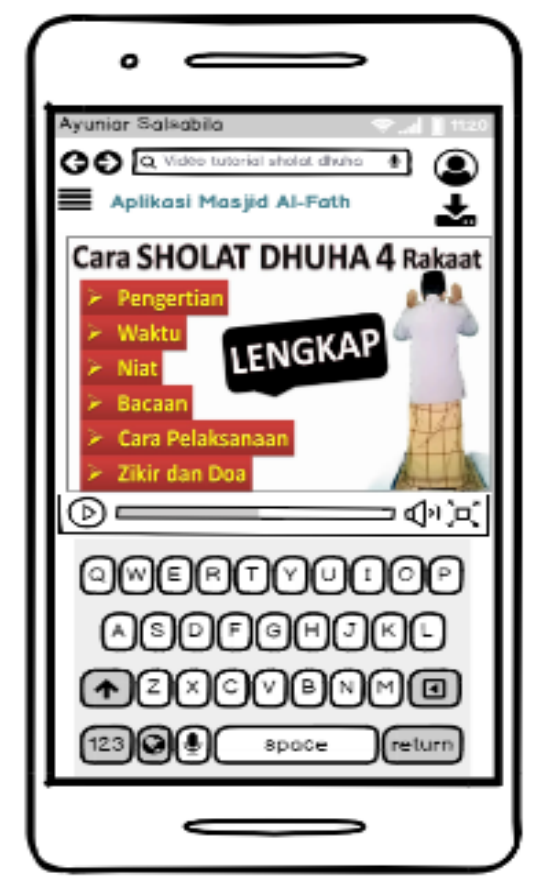

Gambar IV. 6 Interface Design Video Tutorial Sholat, Do'a di Aplikasi Masjid Al-Fath Online 


\section{BAB V}

\section{SOURCE CODE}

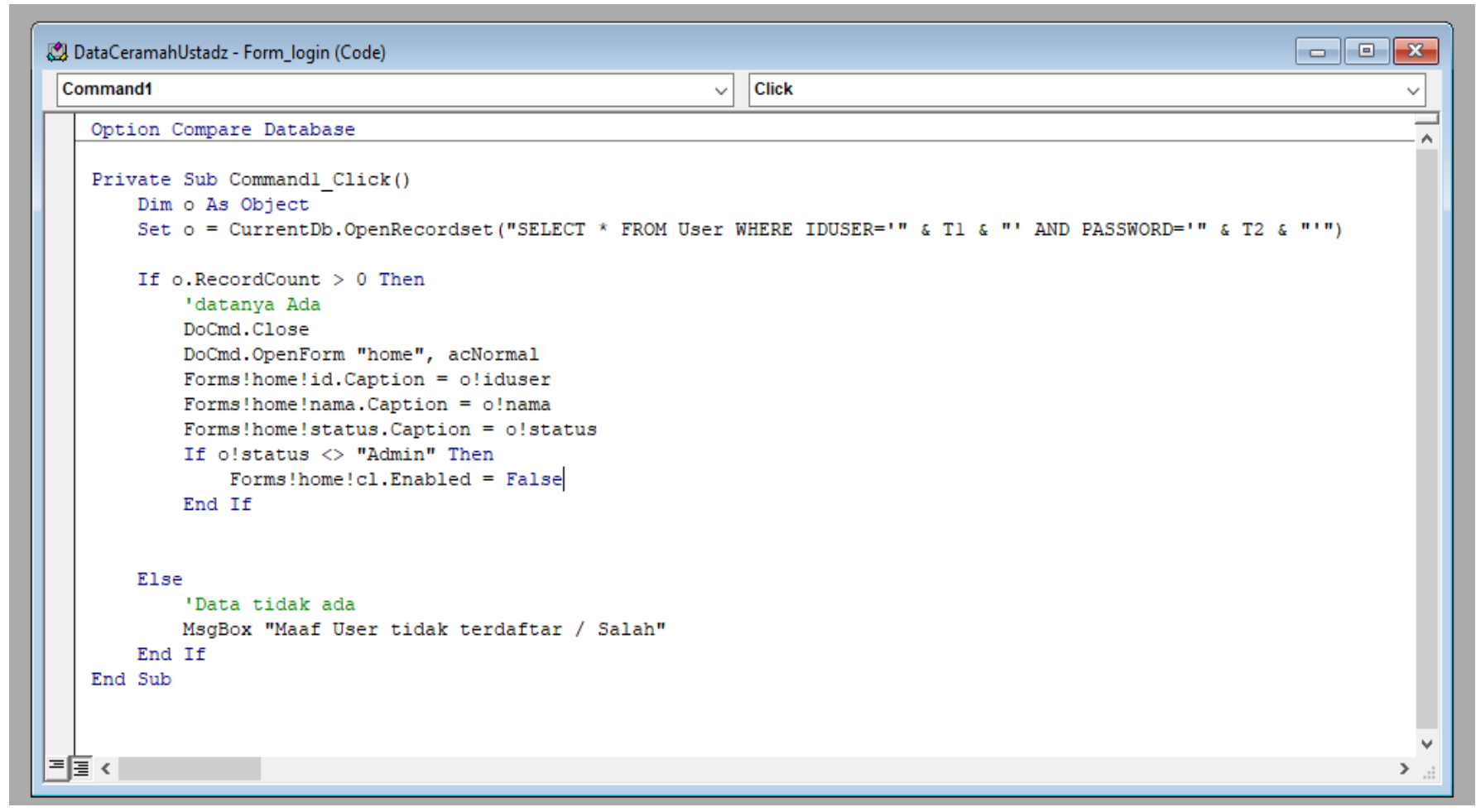

Gambar V. 1 Source Code untuk Login Page Aplikasi Masjid Al-Fath Online di Ms. Access

Berikut merupakan detail dari source code untuk Login Page di Ms Access:

Private Sub Command1_Click()

Dim o As Object

Set $\mathrm{o}=$ CurrentDb.OpenRecordset("SELECT * FROM User WHERE IDUSER='" \& T1 \& "' AND PASSWORD="' \& T2 \& "'")

If o.RecordCount $>0$ Then

'datanya Ada 


\section{DoCmd.Close}

DoCmd.OpenForm "home", acNormal

Forms!home $!$ id.Caption $=$ o! iduser

Forms!home!nama.Caption = o!nama

Forms!home!status.Caption $=$ o!status

If o!status $<>$ "Admin" Then

Forms!home!cl.Enabled $=$ False

End If

Else

'Data tidak ada

MsgBox "Maaf User tidak terdaftar / Salah"

End If

End Sub 


\section{BAB VI}

\section{PENUTUP}

\section{V.1 Kesimpulan}

Aplikasi Masjid Al-Fath Online dapat membantu masyarakat yang ingin beribadah tetapi terhalang oleh wabah pandemic corona. Dalam aplikasi tersebut telah menediakan pilihan kumpulan-kumpulan video tuntunan Sholat wajib dan sunnah, do'a-do'a, ceramah dan khutbah. Tagline dalam aplikasi Masjid Al-Fath Online tersebut yaitu beribadah dengan lebih mudah dan praktis. Jadi, walaupun beribadah hanya bisa dari rumah bisa dengan maksimal. Aplikasi ini di peruntukkan untuk masyarakat yang tinggal di sekitar Masjid Al-Fath Cikampek, Karawang.

\section{V.2 Saran}

Sebaiknya Aplikasi Masjid Al-Fath Online ditambahkan fitur-fitur lainnya seperti fitur pembayaran zakat fitrah, mal secara online, registrasi dan metode pembayaran untuk membeli hewan qurban ketika mendekati hari raya Idul Adha. 


\section{REFERENCES}

Pengertian Acceptance Testing - Sistem Informasi. (2017, April 20). Retrieved from http://www.sistem-informasi.xyz/2017/04/pengertian-acceptance-testing.html

Terapan, A. (2007, Januari 29). Contoh Sederhana Aplikasi Back-End dan Front-End Database di MS Access Dengan Menggunakan DAO. Retrieved from http://accessterapan.blogspot.com/2016/05/contoh-sederhana-aplikasi-back-end-dan.html 